\title{
The Impact of BASEL Accords on the Management of Vietnamese Commercial Banks
}

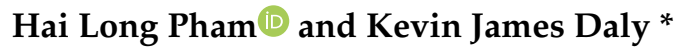 \\ School of business, Western Sydney University, Penrith, NSW 2751, Australia; phamhailong300683@gmail.com \\ * Correspondence: k.daly@westernsydney.edu.au
}

Received: 4 August 2020; Accepted: 24 September 2020; Published: 27 September 2020

\begin{abstract}
This paper is an attempt to empirically examine the impact of Basel Accord regulatory guidelines on the risk-based capital adequacy regulation and bank risk management of Vietnamese commercial banks. Our research aims to assess how Vietnamese commercial banks manage their capital ratio and bank risk under the latest Basel Accord capital adequacy ratio requirements. Building on previous studies, this research uses a simultaneous equation modeling (SiEM) with three-stage least squares regression (3SLS) to analyze the endogenous relationship between risk-based capital adequacy standards and bank risk management. A year dummy variable (dy2013) is included in the model to take account of changes in the regulation of the Vietnamese banking system. Furthermore, we add a value-at-risk variable developed by as an independent variable into equations of the empirical models. The results reveal a significant impact of Basel capital adequacy regulatory pressure on the risk-based capital adequacy standards and bank risk management of Vietnamese commercial banks. Moreover, banks under the latest Basel capital adequacy regulations are induced to reduce risks and increase banks' financial performance.
\end{abstract}

Keywords: Basel accords; risk-based capital adequacy requirement; risk management; three-stage least square (3SLS); simultaneous equation models (SiEM); Vietnamese commercial banks

\section{Introduction}

Risk-based capital adequacy regulation was implemented by the Basel Committee on Banking Regulation and Supervisory Practices in July 1988 to enhance the stability of banks and financial institutions (Jacques and Nigro 1997; Maji Santi 2015). The adoption of risk-based capital standards by a large number of countries in accordance with Basel I, Basel II (2004), and Basel III (2010) risk-based capital adequacy regulation required banks to hold adequate tiered capital based on the level of risk in their portfolio. The primary objective of the risk-based capital adequacy regulation was to ensure banks' capital was sensitive to the risks reflected by banks' portfolios. While the capital adequacy ratio (CAR) of banks complied with the risk-based capital requirements of Basel Accords, the problem regarding the adequacy of the capital requirements during periods of crises remained an open question (Jacques and Nigro 1997). The question led to increased interest in CAR for the banking system, which attracted researchers to study the relationship between capital adequacy regulation and bank risk in both developed and developing countries. This research has produced two main streams of empirical findings. Some researchers found a positive relationship between regulatory capital and bank risk-taking behavior (Ashraf et al. 2016; Danisman and Demirel 2019; Hussain et al. 2019; Jacques and Nigro 1997; Maji and Hazarika 2018; Shrieves and Dahl 1992; Zheng et al. 2017). By contrast, research by (Maji Santi 2015; Sirait and Rokhim 2019; Zhang et al. 2008) found an inverse relationship between capital and bank risk.

The purpose of this study is to empirically examine how risk-based capital adequacy requirements and bank risk are related. Moreover, this study contributes to the existing literature on bank capital 
adequacy ratio and bank risk management by adding explanatory variables, such as value-at-risk and a year dummy in the model.

The simultaneous equation modeling (SiEM) model employing three-stage least squares regression (3SLS) is the most significant development in econometrics being employed to analyze adjustments to the risk-based capital and bank risk management. The significance of this methodology leads us to investigate how the changes in capital adequacy ratio following Basel Accords led to an improvement in bank risk management.

The paper finds there are inversely significant relationships between change in the level of banks' risk and change in capital adequacy ratio. The results imply that Vietnamese commercial banks failed to meet the minimum Capital Adequacy Ratio (CAR) required set by the State Bank Vietnam (SBV). The results may be used to assist SBV in guiding Vietnamese commercial banks by way of improving their capital ratio and take measures to reduce the proportion of risk-weighted assets under the risk-based capital adequacy regulatory standards mandated by the Basel Accords. The results also show a positive influence of the latest Basel Accord on managing capital ratio and bank risk of Vietnamese commercial banks.

\section{Literature Review}

\subsection{Empirical Evidence on Risk-Based Capital Adequacy Requirement and Bank Risk Association}

The Basel capital regulatory framework has become the dominant influence over prudential regulation of financial institutions (Ayadi et al. 2016; Barker 2015; Nguyen 2013). During and after the Global Financial Crises (GFC), governments around the world focused on restoring the health and vitality of their banking systems by requiring strict adherence to international best practice principles and standards, such as those of the Basel capital regulatory framework of the Basel Committee on Banking Supervision (BCBS), and in particular adherence to the Basel III framework with the objective of improving bank regulation (BCBS 2014) (Ayadi et al. 2016; Barker 2015; Dermine 2015; Gavalas 2015; Kruithof 2013; Rubio and Carrasco-Gallego 2016; Sutorova and Teplý 2013).

According to (BCBS 2018; Neanidis 2019; Zetzsche et al. 2017), financial regulators became focused on the optimal functioning of a regulatory and supervisory framework to help mitigate financial uncertainty. Korinek and Sandri (2016) analyzed both the macro-prudential regulation and capital control being ideally adjusted to mitigate the risks to financial stability in emerging economies based on data from East Asian countries. Munhoz et al. (2017) applied Generalized Autoregressive Conditional Heteroscedasticity models (GARCH) to study the volatility of banks across Brazil, Russia, India, and China (BRIC) countries with the objective of discovering how prudential capital regulations contributed to financial stability. Their empirical analysis showed that capital flow instability is less affected in countries that adopted capital control regulation of Basel Accords.

Recently, Ho et al. (2018) found that banks that applied Basel risk-weighted assets management constraints prevented defaults on the debt of banks. Aiyar et al. (2015) study found that raising minimum capital requirements detrimentally affected bank profits, stock prices, and loan supply. However, avoiding the serious consequences of banking crises more than covered those costs. Furthermore, they suggested that liquidity ratios, book capital ratios, and internal risk models of the Basel III guideline must be replaced by a system of reliable rules, encouraging the incorporation with objective information of market-based into a simple and reliable regulatory process.

Andrien and Peirce (2016) demonstrated the impact of the new Basel regulation on the behavior of banks where the required rise of the capital adequacy ratio was reflected by banks boosting their capital and decreasing their risk-weighted assets. However, previous studies by (Kahane 1977; Kim and Santomero 1988) found that the use of the traditional uniform ratio requirement is not a significant means to guarantee the insolvency risk of banks and does not maintain a safe and sound banking system. 
Finally, Phi brought out a new theoretical framework to prove that stricter capital regulation following the Basel Accords is not a binding constraint on the activities of the bank in Vietnam. They investigated the impacts of the Basel II capital requirement on the rate of Vietnamese bank lending and discovered that credit is a risky activity in banking operations, and, consequently, banks react by reducing their lending rate when it has to improve CAR.

The existing works have not reached agreement on proving that risk-based capital requirements following capital regulation of the Basel Accords contribute to the solvency of banks in Vietnam. This study has examined the relationship between the risk-based capital standards of Basel Accords and bank risk management by employing the SiEM model developed by Shrieves and Dahl (1992) via two equations (changes in capital adequacy ratio and risk).

\subsection{An Overview of Vietnamese Commercial Banks}

\subsubsection{Current Risk Situation of the Banking System in VIETNAM}

There are many types of risks related to banking operations, such as credit, operational, and market risk as main risks. Market risk is the risk due to adverse movements of interest rates, exchange rates, stock prices, and market prices of goods (Hendricks and Hirtle 1997; Tuladhar 2017). Operational risk is the risk due to incomplete or erroneous internal processes, human factors, system failures, faults or external factors, which cause financial losses. (Gadzo et al. 2019; Pereira et al. 2018) found that the major negative impacts on Vietnamese banks were the non-financial impacts coinciding with the appearance of foreign bank branches.

Credit risk has been the focus of risk management by regulators and bank management. For banking credit operations, the definition of risk is the ability to lose the principal invested and the amount of interest accrued; these are situations in which the loan is used by the borrower or situations where the borrower cannot currently pay the principal and interest on time (Agwu 2018). Credit risk is the main cause of bad debts of the banking system and coexists with banking operations. Moreover, credit risk has been identified in the initial period of Basel Accord as a core source of risk (BCBS 1988). The main revenue for the commercial bank is from credit activities; according to the SBV Annual Report (2018) these operations brought over $70 \%$ of total income for banks in Vietnam. Therefore, the credit risk is always critical to banks in Vietnam.

\subsubsection{Current Implementation of Basel Accords in Capital Adequacy Requirement (CAR)}

During the reform period, the Vietnamese banking system gradually sought international principles and standards to be suitable for Vietnam's international financial integration. In line with general international principles of Bank for International Settlements (BIS) Risk-weighted assets, particularly Basel I, II, and III, the State Bank of Vietnam and other credit institutions in Vietnam made efforts to improve their monetary and legal reporting requirements by enhancing their management and administration capacity, especially in the sphere of risk management in line with international best practice and standards. In Vietnam, the SBV is directly responsible for managing and supervising the implementation of Basel requirements. As a result, the SBV has continued to add more rules and regulations under the Basel II framework (Comitato di Basilea per la Vigilanza Bancaria 2004). According to SBV Annual Report's (2013; 2014 and 2015), Vietnamese commercial banks maintained only the minimum (8\%) CAR of Risk-weighted assets (RWA). The low CAR of Vietnamese banks poses many challenges and is considered a bottleneck for the growth of the whole system (Aryeetey and Ackah 2011). According to the SBV 2015 report, the CAR of the Vietnamese banking system is at the lowest level in the Association of Southeast Asian Nations (ASEAN) region.

The reason to focus on minimum capital requirements in the context of Vietnamese commercial banks relates to its ineffectiveness in controlling risks. Here, we provide some reasons why Vietnamese banking has failed to control risks. Vietnamese banks typically hedge against risk by resorting to raising capital in a short-term money market, which places tremendous pressure on banks to maintain 
long term capital requirements. In addition, during the Global Financial Crisis, when stock markets declined, Circular (13/2010/TT-NHNN) required banks to increase their CAR by $9 \%$ compared to the previous regulations, which pushed banks to introduce strict credit squeezes. In this situation, the banks tried to find ways to meet their capital requirements by cross-ownership. This resulted in the appearance of banks increasing their capital, but in overall terms, the capital of the banking system as a whole did not increase. In addition, this Circular specifies the level of risk of each bank's assets, but through cross-ownership among banks, the determination of the ultimate purpose of the loan or investment was made increasingly difficult to determine. Finally, the minimum capital adequacy standard addresses a reserve requirement that banks need to maintain in order to cope with risks from the bank's operations).

The implementation of the Basel Accords for improving banking in Vietnam is one of the most important reforms currently undertaken by Vietnamese banks. The banks that operate effectively need to improve and maintain their CAR based on a number of international standards. Previous research by (Nguyen and Huong 2013; Nguyen and Tran 2015) studied the factors that affect the CAR based on the Basel framework, which focused on credit risk and ignored operation and market risk. In their study, they used random effect and fixed-effect models to measure the influence of factors on the CAR of commercial banks in Vietnam. Although Basel Accord appeared more than 30 years ago in 1988, in Vietnam, the application of these Basel standards in banking supervision and management still has many problems, as reported in the above studies. Their research suggests that developing economies are playing catch up with Basel Accords and that the banking systems of developing countries, including Vietnam, have real challenges in the application of Basel Agreements (Nguyen 2013).

\section{Data and Methodology}

\subsection{Summary Statement of Hypothesis}

Empirically, the research question is whether the risk-based capital adequacy regulation of Basel Accords can improve bank risk management of banks in a developing country, such as Vietnam. Taking as the null hypothesis that changes in the capital adequacy ratio have no impact on risk management and vice-versa.

Hypothesis 1. The risk-based capital adequacy regulation of Basel Accords will not improve bank risk management in the Vietnamese commercial banks.

\subsection{Data and Model Specification}

The sample consists of 28 out of 35 licensed commercial banks in Vietnam over the period 2009-2018, employing the disclosed annual reports of Vietnamese commercial banks. The period 2013-2018 is the roadmap of implementing the capital and risk management, according to the Basel Accord for Vietnamese commercial banks. The data is the research analyzed by calculating and comparing the risk-based capital adequacy ratio and bank risk management for each year of the study period.

\subsubsection{Capital Adequacy Ratio (CAR) and Bank Risk}

According to (BCBS 1988), CAR is one of the three Basel III requirements calculated as the ratio of the amount of regulatory capital (Tier 1, 2, and 3) to the total risk-weighted asset, relying on the effects of the Basel Accords, which require banks to have a minimum level of capital as a percentage of risk-weighted assets. Banks with higher CAR are considered to have a higher risk of meeting their financial obligations and more likely to be obligatory during the recession periods (Tuladhar 2017). A major issue in the banking industry after the subprime mortgage problem was capital-based regulation. 
CAR measures the amount of banking capital related to the amount of risk-weighted credit exposure and also legalized in Basel capital regulation (Gadzo et al. 2019). To maintain the minimum capital adequacy ratio, a bank can begin collecting outstanding debts or become reluctant to approve a new loan (Hyun and Rhee 2011). We consider this study would be even-handed to use CAR with data been extracted from the annual reports of banks as an indicator for bank risk management.

$$
\mathrm{CAR}=\text { Regulatory capital (Tier 1, 2, and 3)/Risk-weighted asset }
$$

Bank risk. There are different ways in the existing literature to measure bank risk, such as the ratio of risk-weighted assets to total assets (Andrien and Peirce 2016; Shrieves and Dahl 1992), non-performing assets (Kapoor and Kaur 2018; Maji Santi 2015; Maji and Hazarika 2018), and z-score (Danisman and Demirel 2019; Hussain et al. 2019; Sirait and Rokhim 2019; Zheng et al. 2017). The ratio of risk-weighted assets is widely used in the existing literature to represent bank risk because this ratio correlates with the risky behavior of banks. We use the ratio of risk-weighted assets to total assets for measuring the bank risk of Vietnamese commercial banks.

\subsubsection{Other Explanatory Variables}

Value at Risk (VaR) is a statistic that measures and quantifies the level of financial risk within a bank, portfolio, or position over a specific time frame. Taleb (2007) argued that the so-called "Black Swan" phenomena, which describes an event with a small probability of occurrence but a large adverse impact, could not be measured properly by VaR. Although the Basel framework of the Bank for International Settlements BIS (2009) recommends the use of back-testing and stress-testing approaches to measuring VaR, most quantitative approaches to VaR estimation do not explain how to implement these techniques in practice. Some commentators argue that new approaches are required to address rising fragility (Saunders and Allen 2010). Bernard et al. (2017) measured the scale of model uncertainty of credit risk portfolio models, that is, what is the maximum and minimum VaR of a portfolio of risky loans that can be justified, given a certain amount of available information. We have used JP Morgan Risk Metrics method as used in the study of Uylangco and Li (2016) to measure VaR as formula following:

$$
\begin{gathered}
\mathrm{VaR}=\text { mark-to-market the current portfolio } \times \text { value change of the 1-day returns on } \\
\text { the portfolio } \times \text { confidence level used }
\end{gathered}
$$

Year dummy (dy2013) is similar to (Andrien and Peirce 2016; Ashraf et al. 2016; Shrieves and Dahl 1992), and a year dummy variable is added in the simultaneous equations model. There is only a one-year dummy being equal to 1 in 2013 and years after and 0 otherwise. The year 2013 is added in the model to take account of the implementation of the Basel Accords for roadmap from 2013-2018 by the State Bank of Vietnam's decision. Banks knew at this time that they have to adhere to the risk-based capital standards of the Basel Accords.

The regulatory pressure (REG) variable tells us how banks behave when they are under pressure, i.e., under capital adequacy requirement (CAR), liquidity coverage ratio, and net stable funding ratio. As a requirement of Basel III regulations, the financial institutions are asked to maintain a total capital higher than $8 \%$ (Andrien and Peirce 2016). The regulatory pressure variable is a dummy variable, equal to 1 if CAR less than $8 \%$ is the minimum capital requirement of Basel Accords and equal to 0 otherwise.

The non-performing loan consists of all loans overdue on principal and interest payments. Macit (2017) found that banks with higher equity to total assets ratio and a higher net income margin are expected to have a higher nonperforming loan ratio (NPLR), whereas an increase in net loans to total assets ratio is expected to reduce the non-performing loan. On the other hand, Ozili (2019) found that the non-performing loan is negatively associated with the CAR ratio, implying that banking 
sectors with greater regulatory capital experience fewer non-performing loans. The equation for the non-performing loan ratio is the non-performing loans divided by total loans.

$$
\text { NPLR }=\text { Non-performing loans/Total loans }
$$

Return on average equity (ROAE) is a ratio of current profit to total equity, which reflects how the real investment of bank equity generates profit. Moreover, it shows how is bank performance and is used as a metric of bank performance via examining the relationship between risk management and bank performance in previous studies, such as (Mollah et al. 2017; Tuladhar 2017). Thus, ROAE is one of the indicators of bank performance.

$$
\text { ROAE }=\text { Profit/Total average equity }
$$

dSize of the bank (SIZE). (Andrien and Peirce 2016) affirmed that the SIZE variable is incorporated in the capital and risks the model equation to capturing size effect. This variable represents the size of the bank and is computed as the natural logarithm of the total assets (Ho et al. 2018). Tuladhar (2017) used the bank size as a control variable to find the impact of risk management on bank performance. Moreover, she also found a positive relationship between bank size and bank performance, and the greater banks have a better performance.

$$
\mathrm{SIZE}=\operatorname{Ln}(\text { Total assets })
$$

\subsection{Model Specification and Estimation Technique}

In line with the work of (Andrien and Peirce 2016), where the capital adequacy ratio and risk were built to test the efficiency of the bank risk management, the equations below are estimated to examine the efficiency of bank risk management. Our empirical analysis of Vietnamese commercial banks is based on the SiEM model of Shrieves and Dahl (1992) and recently was used by Andrien and Peirce (2016). However, our empirical model will develop and improve the equation in the previous model developed by (Andrien and Peirce 2016) by changing the dependent variable from a change in levels of capital to a change in capital adequacy ratio, which is more efficient for examining how risk-based capital adequacy regulation is based on Basel Accord to improve the efficiency of the bank risk management. In addition, we add the value at risk (VAR) variable as an independent variable into the equations of the empirical model. The VAR is a new approach developed by (Saunders and Allen 2010) to help to measure and quantify the level of risks within a bank. Our empirical model is composed of two equations below, which are estimated to examine the efficiency of bank risk management: one relates to change in capital adequacy ratio ( $\triangle \mathrm{CAR})$ and the other change in bank risk levels $(\triangle \mathrm{RISK})$. Moreover, if we focus on the risk part, a significant and positive coefficient for $\triangle \mathrm{CAR}$ increases capital adequacy ratio in the chorus with risk ratio, while a significant and negative coefficient for $\triangle \mathrm{CAR}$ results in a higher capital adequacy ratio, leading to reduced risk ratio. We use the following Equations (6) and (7) for the empirical analysis:

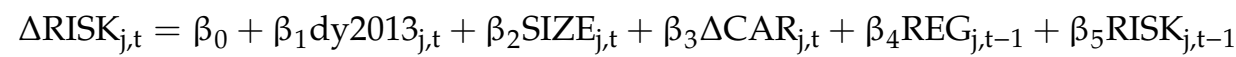

$$
\begin{aligned}
& +\beta_{6} \mathrm{VAR}_{\mathrm{j}, \mathrm{t}}+\beta_{7} \mathrm{NPLR}_{\mathrm{j}, \mathrm{t}}+\beta_{8} \mathrm{ROAE}_{\mathrm{j}, \mathrm{t}}+\beta_{9} \mathrm{CAR}_{\mathrm{j}, \mathrm{t}}+\mathrm{U}_{\mathrm{j}, \mathrm{t}} \\
& \Delta \mathrm{CAR}_{\mathrm{j}, \mathrm{t}}=\alpha_{0}+\alpha_{1} \mathrm{ROAE}_{\mathrm{j}, \mathrm{t}}+\alpha_{2} \mathrm{NPLR}_{\mathrm{j}, \mathrm{t}}+\alpha_{3} \Delta \mathrm{RISK}_{\mathrm{j}, \mathrm{t}}+\alpha_{4} \mathrm{REG}_{\mathrm{j}, \mathrm{t}-1}+\alpha_{5} \mathrm{VAR}_{\mathrm{j}, \mathrm{t}}+\alpha_{6} \mathrm{CAR}_{\mathrm{j}, \mathrm{t}}
\end{aligned}
$$

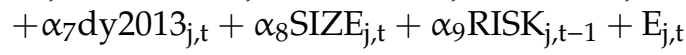

where:

* ROAE represents the current profit and is measured by the return on total equity;

* SIZE represents the size of the bank and is computed as the natural logarithm of the total assets;

* $\quad$ REG represents the Basel III regulatory pressure variable; 
* NPLR represents the non-performing loan ratio;

* Bank j at time $t$

$$
\frac{\Delta \mathrm{CAR}_{\mathrm{j}, \mathrm{t}}}{\mathrm{CAR}_{\mathrm{j}, \mathrm{t}}}=\frac{\Delta \mathrm{K}_{\mathrm{j}, \mathrm{t}}}{\mathrm{K}_{\mathrm{j}, \mathrm{t}}} * \frac{\Delta \mathrm{RISK}_{\mathrm{j}, \mathrm{t}}}{\mathrm{RISK}_{\mathrm{j}, \mathrm{t}}} * \frac{\Delta \mathrm{A}_{\mathrm{j}, \mathrm{t}}}{\mathrm{A}_{\mathrm{j}, \mathrm{t}}}
$$

where:

* $\quad$ CAR $[=K /$ total RWA $=\mathrm{K} /(\mathrm{CRWA}+\mathrm{MRWA}+\mathrm{ORWA})]$ represents the capital adequacy ratio

* CRWA represents credit risk-weighted asset; MRA represents market risk-weighted asset; ORWA represents operational risk-weighted asset;

* $\quad$ RISK (=total RWA/A) represents the total risk (=credit risk + operational risk + risk market risk)

* $\quad \mathrm{K}$ and $\mathrm{A}$ represent the total capital and total assets

All variables of the model excluding Risk are from Fitch Solutions. Risk is measured in two steps as following:

$\operatorname{RWA}_{\mathrm{j}, \mathrm{t}}=\mathrm{K}_{\mathrm{j}, \mathrm{t}} / \mathrm{CAR}_{\mathrm{j}, \mathrm{t}}$

$\operatorname{RISK}_{\mathrm{j}, \mathrm{t}}=\mathrm{RWA}_{\mathrm{j}, \mathrm{t}} / \mathrm{A}_{\mathrm{j}, \mathrm{t}}$

where: * Bank $\mathrm{j}$ at time $\mathrm{t}$

Consistent with recent researches, a three-stage least-squares regression analysis is used to estimate the simultaneous equation model. There is at least one endogenous variable on the right-hand side of each equation of this model. The two-stage least square (2SLS) is less efficient than the three-stage least squares method. The term of three-stage least squares (3SLS) refers to a methodology of estimation that combines the system equation. Three-stage least squares regression is used to establish the functional relationship between two or more independent variables and a given endogenous variable.

\section{Results and Discussions}

\subsection{Descriptive Statistics}

Table 1 shows some descriptive statistics from this study, the observations from 28 banks cover a period of 10 years, the data is sourced from Fitch, which is only reported annually and covers 28 of the 35 licensed Vietnam's commercial banks over the ten-year period 2009-2018, providing a total of 280 observations (Obs) the remaining seven banks did not submit data or their data was not recorded by Fitch. The mean CAR is $14 \%$, and the maximum (Max) and minimum (Min) are $48.6 \%$ and $4.4 \%$, respectively. The minimum CAR is an indication that some commercial banks did not reach the CAR standard of the Basel Accords; however, the mean of $14 \%$ does comply with the minimum standard of $8 \%$ required by SBV over the sample period. Regarding the non-performing loan ratio, the average is $2.4 \%$, where the maximum is $11.4 \%$, and the minimum is $0 \%$. Over the period 2009 to 2018 , the return on average equity showed that the banks were profitable with the mean of ROAE of $9.6 \%$ and a maximum of $29 \%$. The VAR among the commercial banks in Vietnam varies from $1.5 \%$ to $4.4 \%$, with a mean of $3.1 \%$ and a standard deviation of $0.866 \%$, which indicates that banks face ongoing risk in their operations. From Table 1, the SIZE of Vietnamese commercial banks is 17.551, with a standard deviation (STD.Dev) of 3.68865. The minimum and maximum values are 0.088 and 20.996, respectively. This indicates that banks vary in SIZE, with some banks well-capitalized and positioned to reduce their bank risk and minimize risk exposure. 
Table 1. Summary statistics of the dataset from 2009 to 2018.

\begin{tabular}{cccccc}
\hline Variable & Obs & Mean & Std. Dev. & Min & Max \\
\hline$\Delta$ RISK $_{\mathrm{j}, \mathrm{t}}$ & 280 & 0.004 & 0.11040 & -0.384 & 0.490 \\
$\Delta$ CAR $_{\mathrm{j}, \mathrm{t}}$ & 280 & -0.004 & 0.05607 & -0.210 & 0.245 \\
IIZE $_{\mathrm{j}, \mathrm{t}}$ & 280 & 17.551 & 3.68865 & 0.088 & 20.996 \\
RISK $_{\mathrm{j}, \mathrm{t}-1}$ & 280 & 0.742 & 0.13483 & 0.442 & 1.252 \\
dy2013 & 280 & 0.500 & 0.50090 & 0 & 1.000 \\
\hline VAR $_{\mathrm{j}, \mathrm{t}}$ & 280 & 0.031 & 0.00866 & 0.015 & 0.044 \\
ROAE $_{\mathrm{j}, \mathrm{t}}$ & 280 & 0.096 & 0.06576 & 0 & 0.290 \\
REG $_{\mathrm{j}, \mathrm{t}-1}$ & 280 & 0.846 & 0.36118 & 0 & 1.000 \\
NPLR $_{\mathrm{j}, \mathrm{t}}$ & 280 & 0.024 & 0.01620 & 0 & 0.114 \\
$\mathrm{CAR}_{\mathrm{j}, \mathrm{t}}$ & 280 & 0.140 & 0.07337 & 0.044 & 0.486 \\
\hline
\end{tabular}

Table 2 shows the descriptive statistics of the variables for the data set of two periods-before (2009-2012) and after (2013-2018) Vietnamese commercial banks were fully affected by Basel Accords. These Tables, combined reveal that the means of variables are changed after the Vietnamese commercial banks implemented the capital adequacy requirement and risk management, according to the Basel Accord, as required by the State Bank of Vietnam 2013. The means of NPLR, RISK, and VAR after affected Basel Accords (2.2\%, $71.8 \%$, and $2.7 \%$, respectively) are smaller than before affected $(2.7 \%$, $78 \%$, and $3.6 \%$, respectively). They give indications of Basel Accords, impacting on reducing the banks' risk and bad loan. Further, the banks' performance evaluation variable ROAE decreases after affected Basel Accords. However, Table 2 reveals that means of ROAE have improved year by year in the impacting period 2013-2018. To maintaining CAR, both periods still keep sufficient CAR to meet the Basel standards.

Table 2. (a) Summary statistics of the dataset from 2013 to 2018 (after fully affected by Basel Accords).

(b) Summary statistics of the dataset from 2009 to 2012 (before fully affected by Basel Accords).

\begin{tabular}{cccccc}
\hline & \multicolumn{5}{c}{ (a) } \\
\hline Variable & Obs & Mean & Std. Dev. & Min & Max \\
\hline$\Delta$ RISK $_{\mathrm{j}, \mathrm{t}}$ & 168 & 0.015 & 0.120827 & -0.355 & 0.490 \\
$\Delta$ CAR $_{\mathrm{j}, \mathrm{t}}$ & 168 & -0.012 & 0.038573 & -0.172 & 0.245 \\
SIZE $_{\mathrm{j}, \mathrm{t}}$ & 168 & 17.845 & 3.748211 & 0.108 & 20.996 \\
RISK $_{\mathrm{j}, \mathrm{t}-1}$ & 168 & 0.718 & 0.12493 & 0.442 & 1.009 \\
VAR $_{\mathrm{j}, \mathrm{t}}$ & 168 & 0.027 & 0.008785 & 0.015 & 0.041 \\
ROAE $_{\mathrm{j}, \mathrm{t}}$ & 168 & 0.082 & 0.063005 & 0 & 0.290 \\
REG $_{\mathrm{j}, \mathrm{t}-1}$ & 168 & 0.857 & 0.350973 & 0 & 1.000 \\
NPLR $_{\mathrm{j}, \mathrm{t}}$ & 168 & 0.022 & 0.012871 & 0.003 & 0.073 \\
CAR $_{\mathrm{j}, \mathrm{t}}$ & 168 & 0.126 & 0.063575 & 0.045 & 0.486 \\
\hline & & & $\mathbf{( b )}$ & & \\
\hline Variable & Obs & Mean & Std. Dev. & Min & Max \\
\hline$\Delta$ RISK $_{\mathrm{j}, \mathrm{t}}$ & 112 & -0.014 & 0.0902477 & -0.384 & 0.168 \\
$\Delta$ CAR $_{\mathrm{j}, \mathrm{t}}$ & 112 & 0.008 & 0.073554 & -0.210 & 0.229 \\
SIZE $_{\mathrm{j}, \mathrm{t}}$ & 112 & 17.111 & 3.568691 & 0.088 & 20.241 \\
RISK $_{\mathrm{j}, \mathrm{t}-1}$ & 112 & 0.780 & 0.1409824 & 0.498 & 1.252 \\
VAR $_{\mathrm{j}, \mathrm{t}}$ & 112 & 0.036 & 0.0044503 & 0.032 & 0.044 \\
ROAE $_{\mathrm{j}, \mathrm{t}}$ & 112 & 0.118 & 0.0639004 & 0.010 & 0.280 \\
REG $_{\mathrm{j}, \mathrm{t}-1}$ & 112 & 0.830 & 0.3770056 & 0 & 1.000 \\
NPLR $_{\mathrm{j}, \mathrm{t}}$ & 112 & 0.027 & 0.0199135 & 0 & 0.114 \\
CAR $_{\mathrm{j}, \mathrm{t}}$ & 112 & 0.160 & 0.0823226 & 0.044 & 0.416 \\
\hline
\end{tabular}

Table 3 shows a correlation matrix between variables and the test outcomes of the multicollinearity problem. According to Cooper and Schindler (2003), the problem of multicollinearity is when the value 
is bigger than 0.8. Based on the correlation results in Table 3, it shows that there are no correlations to meet 0.8 or bigger rule and, therefore, no problem of multicollinearity. Moreover, correlation analyses among all dependent and independent variables and their related first differences and lags are conducted, where the correlation between change in risk level and change in capital adequacy ratio is shown to be negative. Further, changes in capital adequacy ratio are positive relatively-related lags in risk and return on average equity, and bank size is found to be inversely correlated to the change in risk level. 3SLS regression is used to illuminate the strength of these relationships.

Table 3. Correlations among variables.

\begin{tabular}{|c|c|c|c|c|c|c|c|c|c|c|}
\hline & $\Delta$ RISK $_{\mathbf{j}, \mathrm{t}}$ & $\Delta \mathrm{CAR}_{\mathbf{j}, \mathbf{t}}$ & SIZE $_{j, t}$ & $\mathrm{REG}_{\mathrm{j}, \mathrm{t}-1}$ & RISK $_{j, t-1}$ & dy2013 & $\mathrm{VAR}_{\mathbf{j}, \mathbf{t}}$ & $\operatorname{ROAE}_{j, t}$ & $\operatorname{NPLR}_{\mathbf{j}, \mathrm{t}}$ & $\mathrm{CAR}_{\mathrm{j}, \mathrm{t}}$ \\
\hline$\Delta \mathrm{RISK}_{\mathrm{j}, \mathrm{t}}$ & 1.0000 & & & & & & & & & \\
\hline$\Delta \mathrm{CAR}_{\mathrm{j}, \mathrm{t}}^{\mathrm{j}, \mathrm{s}}$ & -0.2125 & 1.0000 & & & & & & & & \\
\hline $\operatorname{SIZE}_{\mathrm{j}, \mathrm{t}}$ & -0.0491 & -0.0438 & 1.0000 & & & & & & & \\
\hline $\mathrm{REG}_{\mathrm{j}, \mathrm{t}-1}^{\mathrm{j}}$ & 0.0458 & -0.1163 & -0.1745 & 1.0000 & & & & & & \\
\hline RISK $_{j, t-1}$ & -0.3806 & 0.2788 & -0.1092 & -0.2508 & 1.0000 & & & & & \\
\hline dy2013 & 0.1979 & -0.1488 & 0.1159 & -0.0297 & -0.1990 & 1.0000 & & & & \\
\hline $\mathrm{VAR}_{\mathrm{j}, \mathrm{t}}$ & 0.0285 & 0.1225 & -0.0749 & -0.0882 & 0.1550 & -0.5398 & 1.0000 & & & \\
\hline $\mathrm{ROAE}_{\mathrm{j}, \mathrm{t}}$ & 0.0079 & 0.0504 & 0.0143 & -0.2189 & 0.0125 & -0.1730 & 0.2370 & 1.0000 & & \\
\hline$N L R_{j, t}$ & -0.0494 & 0.0846 & -0.2141 & 0.1058 & 0.0102 & -0.2331 & 0.0887 & -0.2095 & 1.0000 & \\
\hline $\mathrm{CAR}_{\mathrm{j}, \mathrm{t}}$ & -0.1911 & 0.2852 & -0.1972 & 0.2680 & 0.0744 & -0.2839 & 0.1514 & -0.1975 & 0.0984 & 1.0000 \\
\hline
\end{tabular}

\subsection{Results of the 3SLS Model}

The outcomes for 3SLS regression are given in Table 4 for the entire sample. Table 4 contains the beta $(\beta)$ coefficients and alpha $((\alpha)$ coefficients of the two independent (endogenous) variables ( $\triangle$ RISK and $\triangle$ CAR). The coefficients are indicators of the predictions of individual variables. In the regression result shown in Table 4, we expect to find that banks' capital adequacy ratio changes during the pressure of risk-based capital regulation set by SBV based on Basel Accords. Furthermore, we expect to recognize that regulatory authority influences their risk level and capital adequacy.

The results from 3SLS regression of the change in risk level (Equation (6)) and the change in capital adequacy ratio (Equation (7)) indicate that the coefficient estimations of $\triangle$ RISK and $\triangle C A R$ are found to be both negative at $1 \%$ level of significance. The significant negative impact of $\triangle$ RISK on $\triangle \mathrm{CAR}$ implies that total bank risk tends to increase when risk-based capital decreases. Conversely, the impact of $\triangle \mathrm{CAR}$ on $\triangle \mathrm{RISK}$ shows a significant negative relationship. These results indicate that when Vietnamese commercial banks adjust their capital adequacy ratio to meet the risk-based capital standards of Basel Accords, the results appear to indicate that banks experience less risk-sensitive exposure for their capital investment strategy. In Table 4, an increase of one percentage point in the capital adequacy ratio decreases the average total risk ratio by 0.0827 percentage points, whereas decreasing CAR by one (1) percentage point coincides with increasing the total risk ratio by 0.3036 percentage points. Conversely, the implication here is that an increase in Vietnamese banks' CAR allows banks to operate with less risk exposure. The negative relationship between CAR and risk exposure experienced by Vietnamese banks is consistent with the finding of Kapoor and Kaur (2018); Maji Santi (2015), and Siddika and Haron (2019).

In (Equation (6)), the change in risk has a negative effect on SIZE, which is significant at 5\%; however, the change in capital adequacy ratio (Equation (7)) is positive and non-significant. The observed negative impact of bank size on risk level minimizes potential risks. The implication here is that bigger banks have more capital capacity and more diversification opportunities, which, in turn, reduce risk in their operations. This result is in line with the findings of Hadjixenophontos and Christodoulou-Volos (2018) and Kapoor and Kaur (2018), who observed a negative statistically significant relationship between bank size and risk.

Banks who have regulatory capital adequacy ratios below the minimum CAR as required by SBV following Basel Accords observe more regulatory pressure and have less independence compared to 
banks that fulfill the regulators' minimum capital requirements. In Table 4, coefficients on lags of the dummy regulatory requirement REG are all negative, with the coefficient of lagged REG ( REG $\left._{j, t-1}\right)$ in simultaneous Equation (7), indicating significance, confirming considerable persistence in maintaining and improving capital adequacy ratio in the Vietnamese banking system.

In Table 4, the estimated coefficients of lagged RISK (RISK $\mathrm{j}_{\mathrm{j}, \mathrm{t}-1}$ ) in both Equations (6) and (7) are significant and negative, confirming the findings of previous studies (Kapoor and Kaur 2018; Maji Santi 2015). Furthermore, the results from simultaneous Equation (6) indicate that the change in the level of risk is negatively influenced by past risk.

The coefficient of the dummy variable dy 2013 corresponding to the change in risk level is positive and significant at $1 \%$ level. This implies that from the year 2013, the assessment of risk-weighted assets of Vietnamese banks has improved and corresponds to the standards of the Basel Accords.

The estimated coefficient of ROAE in Equation (7) (Table 4) is positive and significant, with the change in capital ratio at a $5 \%$ level of significance. This indicates that the banks have enhanced capital base and improved CAR, according to the capital requirement of SBV. This result is consistent with the findings of Maji and Hazarika (2018) in the case of 39 listed Indian commercial banks, where there appears to be a positive influence of ROA on capital adequacy ratio with the implication that banks have increased their profitability by meeting capital regulation.

In the $\triangle C A R$ equation, the coefficient of NPLR is found to be positive and significant. This result indicates that in order to achieve the goal of optimizing the value of banks' return on equity, commercial banks are continually extending credit irrespective of the quality of those loans.

Table 4. Three-stage least-squares regression on the simultaneous equations models.

\begin{tabular}{|c|c|c|c|c|c|c|}
\hline Equation & Obs & Parms & RMSE & R-sq & chi2 & $p$-Value \\
\hline$\Delta$ RISK & 280 & 9 & 0.0968018 & 0.2284 & 90.50 & 0 \\
\hline \multirow[t]{2}{*}{$\triangle \mathrm{CAR}$} & 280 & 9 & 0.0505304 & 0.1849 & 71.00 & 0 \\
\hline & Coef. & Std. Err. & $\mathrm{z}$ & $\mathrm{P}>\mathrm{z}$ & \multicolumn{2}{|c|}{$\begin{array}{c}\text { [95\% Conf. [99\% } \\
\text { Conf Interval] }\end{array}$} \\
\hline \multicolumn{7}{|l|}{$\Delta$ RISK } \\
\hline$\triangle \mathrm{CAR}$ & $-0.3036^{* * *}$ & 0.1138 & -2.67 & 0.008 & -0.5266 & -0.0807 \\
\hline $\mathrm{SIZE}_{\mathrm{j}, \mathrm{t}}$ & $-0.0038^{* *}$ & 0.0017 & -2.31 & 0.021 & -0.0071 & -0.0006 \\
\hline $\mathrm{REG}_{\mathrm{j}, \mathrm{t}-1}$ & -0.0050 & 0.0181 & -0.28 & 0.783 & -0.0404 & 0.0304 \\
\hline RISK $_{j, t-1}^{\prime \prime \prime}$ & $-0.2769^{* * *}$ & 0.0475 & -5.83 & 0 & -0.3700 & -0.1837 \\
\hline dy2013 & $0.0456^{* * *}$ & 0.0147 & 3.10 & 0.002 & 0.0167 & 0.0744 \\
\hline $\mathrm{VAR}_{\mathrm{j}, \mathrm{t}}$ & $2.6839 * * *$ & 0.8067 & 3.33 & 0.001 & 1.1028 & 4.2650 \\
\hline $\mathrm{CAR}_{\mathrm{j}, \mathrm{t}}$ & -0.1637 * & 0.0918 & -1.78 & 0.075 & -0.3437 & 0.0163 \\
\hline $\mathrm{ROAE}_{\mathrm{j}, \mathrm{t}}$ & 0.0568 & 0.0816 & 0.70 & 0.486 & -0.1031 & 0.2167 \\
\hline $\mathrm{NPLR}_{\mathrm{j}, \mathrm{t}}$ & -0.0859 & 0.3832 & -0.22 & 0.823 & -0.8369 & 0.6652 \\
\hline Constant & $0.1945^{* * *}$ & 0.0693 & 2.81 & 0.005 & 0.0586 & 0.3303 \\
\hline \multicolumn{7}{|l|}{$\triangle \mathrm{CAR}$} \\
\hline$\Delta$ RISK & $-0.0827^{* * *}$ & 0.0310 & -2.67 & 0.008 & -0.1435 & -0.0220 \\
\hline $\mathrm{SIZE}_{\mathrm{j}, \mathrm{t}}$ & 0.0003 & 0.0009 & 0.32 & 0.745 & -0.0014 & 0.0020 \\
\hline $\mathrm{REG}_{\mathrm{j}, \mathrm{t}-1}$ & $-0.0187^{* *}$ & 0.0094 & -2.00 & 0.046 & -0.0371 & -0.0004 \\
\hline RISK $_{j, t-1}$ & $0.0718^{* * *}$ & 0.0259 & 2.77 & 0.006 & 0.0210 & 0.1226 \\
\hline dy2013 & 0.0064 & 0.0078 & 0.82 & 0.414 & -0.0089 & 0.0217 \\
\hline $\mathrm{VAR}_{\mathrm{j}, \mathrm{t}}$ & 0.2951 & 0.4291 & 0.69 & 0.492 & -0.5459 & 1.1360 \\
\hline $\mathrm{CAR}_{\mathrm{j}, \mathrm{t}}$ & $0.2270^{* * *}$ & 0.0462 & 4.91 & 0 & 0.1364 & 0.3177 \\
\hline $\mathrm{ROAE}_{\mathrm{j}, \mathrm{t}}$ & $0.0919 * *$ & 0.0423 & 2.17 & 0.030 & 0.0091 & 0.1748 \\
\hline $\mathrm{NPLR}_{\mathrm{j}, \mathrm{t}}$ & 0.3123 * & 0.1992 & 1.57 & 0.080 & -0.0780 & 0.7027 \\
\hline Constant & $-0.10611^{* * *}$ & 0.036138 & -2.94 & 0.003 & -0.17694 & -0.03528 \\
\hline
\end{tabular}

$* * *, * *$, and $*$ represent statistical significance at the $1 \%, 5 \%$, and $10 \%$ levels, respectively, in a two-tailed $t$-test. Obs = Observations, Parms = parameter built-in function, RMSE = Root Mean Square Error, R-sq. = r-squared, chi2 $=$ Chi-squared test. 


\section{Conclusions}

This paper has adopted a SiEM model to estimate the effect of changes in the level of risk on changes in the capital adequacy ratio for commercial banks operating in Vietnam, employing cross-section data on a sample of 28 Vietnamese commercial banks over a ten-year period from 2009 to 2018. The modeling has employed a 3SLS regression technique to estimate a simultaneous equation model, as developed by Shrieves and Dahl (1992). The paper finds there are inversely significant relationships between change in the level of banks' risk and change in capital adequacy ratio. The results imply that Vietnamese commercial banks have failed to meet the minimum CAR required set by the SBV. The results may be used to assist SBV in guiding Vietnamese commercial banks by way of improving their capital ratio and take measures to reduce the proportion of risk-weighted assets under the risk-based capital adequacy regulatory standards mandated by the Basel Accords. The results also show a positive influence of the latest Basel Accord on managing capital ratio and bank risk of Vietnamese commercial banks. Further, regulatory pressure induced by the Basel Accord has encouraged banks to improve their capital to meet a minimum required risk-based capital and to cope with future risks. Briefly, this paper has indicated that the risk-based capital adequacy standard and bank risk management of Vietnamese commercial banks following the Basel Accord seem to be effective and have been improved over period studies.

Author Contributions: Conceptualization, K.J.D. and H.L.P.; methodology, K.J.D.; software, K.J.D.; validation, K.J.D. and H.L.P.; formal analysis, K.J.D.; investigation, H.L.P.; resources, H.L.P.; data curation, H.L.P.; writing—original draft preparation, H.L.P.; writing—review and editing, K.J.D.; visualization, K.J.D.; supervision, K.J.D.; project administration, K.J.D.; funding acquisition, K.J.D. All authors have read and agreed to the published version of the manuscript.

Funding: This research received no external funding.

Conflicts of Interest: The authors declare no conflict of interest.

\section{References}

Agwu, Edwin. 2018. Credit Risk Management: Implications on Bank Performance and Lending Growth. Available online: https://ssrn.com/abstract=3122501 (accessed on 20 February 2020).

Aiyar, Shekhar, Charles W. Calomiris, and Tomasz Wieladek. 2015. Bank capital regulation: Theory, empirics, and policy. IMF Economic Review 63: 955-83. [CrossRef]

Andrien, Gauthier, and Robert Peirce. 2016. The Impact of the Basel III Accord on Commercial Banks' Capital and Risk: Empirical Analysis for the European Union and the United States. Available online: http://hdl.handle.net/2078.1/thesis:7819 (accessed on 20 February 2020).

Aryeetey, Ernest, and Charles Ackah. 2011. The Global Financial Crisis and African Economies: Impact and Transmission Channels. African Development Review/Revue Africaine de Developpement 23: 407-20. [CrossRef]

Ashraf, Badar, Sidra Arshad, and Yuancheng Hu. 2016. Capital regulation and bank risk-taking behavior: Evidence from Pakistan. International Journal of Financial Studies 4: 16. [CrossRef]

Ayadi, Rym, Sami Ben Naceur, Barbara Casu, and Barry Quinn. 2016. Does Basel compliance matter for bank performance? Journal of Financial Stability 23: 15-32. [CrossRef]

Barker, Felicity. 2015. The Reserve Bank's application of the Basel III capital requirements for banks. Reserve Bank of New Zealand Bulletin 78: 1-19.

BCBS. 1988. International Convergence of Capital Measurement and Capital Standards. Basel: Bank for International Settlements. Available online: https://www.bis.org/publ/bcbsc111.htm (accessed on 12 February 2020).

BCBS. 2014. Basel III Leverage Ratio Framework and Disclosure Requirements. Basel: Bank for International Settlements.

BCBS. 2018. History of the Basel Committee. Available online: https://www.bis.org/bcbs/history.htm (accessed on 12 February 2020).

Bernard, Carole, Ludger Rüschendorf, Steven Vanduffel, and Jing Yao. 2017. How robust is the value-at-risk of credit risk portfolios? The European Journal of Finance 23: 507-34. [CrossRef]

BIS. 2009. Revisions to the Basel II Market Risk Framework. Basel: Basel Committee Publications, Bank for International Settlements. 
Comitato di Basilea per la Vigilanza Bancaria. 2004. International Convergence of Capital Measurement and Capital Standards: A Revised Framework. Basel: Bank for International Settlements. Available online: https://www.bis.org/publ/bcbs107.htm (accessed on 20 February 2020).

Cooper, Donald R., and Pamela S. Schindler. 2003. Business Research Methods. New York: McGraw-Hill.

Danisman, Gamze Ozturk, and Pelin Demirel. 2019. Bank risk-taking in developed countries: The influence of market power and bank regulations. Journal of International Financial Markets, Institutions and Money 59: 202-17. [CrossRef]

Dermine, Jean. 2015. Basel III leverage ratio requirement and the probability of bank runs. Journal of Banking $\mathcal{E}$ Finance 53: 266-77.

Gadzo, Samuel Gameli, Holy Kwabla Kportorgbi, and John Gartchie Gatsi. 2019. Credit risk and operational risk on financial performance of universal banks in Ghana: A partial least squared structural equation model (PLS SEM) approach. Cogent Economics \& Finance 7: 2019.

Gavalas, Dimitris. 2015. How do banks perform under Basel III? Tracing lending rates and loan quantity. Journal of Economics and Business 81: 21-37. [CrossRef]

Hadjixenophontos, Andreas, and Christos Christodoulou-Volos. 2018. Financial Crisis and Capital Adequacy Ratio: A Case Study for Cypriot Commercial Banks. Journal of Applied Finance and Banking 8: 87-109.

Hendricks, Darryll, and Beverly Hirtle. 1997. Bank capital requirements for market risk: The internal models approach. Economic Policy Review 3.

Ho, Thanh Tung, Belás Jaroslav, and Baideldinova Tatyana. 2018. How do banks implement the capital regulation requirement? Journal of International Studies 11: 161-75. [CrossRef]

Hussain, Muhammad Sajjad, Muhammad Muhaizam Musa, and Abdelnaser Omran. 2019. The Impact of Regulatory Capital on Risk Taking By Pakistani Banks. Seisense Journal of Management 2: 94-103. [CrossRef]

Hyun, Jung-Soon, and Byung-Kun Rhee. 2011. Bank capital regulation and credit supply. Journal of Banking $\mathcal{E}$ Finance 35: 323-30.

Jacques, Kevin, and Peter Nigro. 1997. Risk-based capital, portfolio risk, and bank capital: A simultaneous equations approach. Journal of Economics and Business 49: 533-47. [CrossRef]

Kahane, Yehuda. 1977. Capital adequacy and the regulation of financial intermediaries. Journal of Banking $\mathcal{E}$ Finance 1: 207-18.

Kapoor, Samriti, and Mandeep Kaur. 2018. The Impact of Basel Norms on the Capital and Risk Behavior of Indian Banks. IUP Journal of Financial Risk Management 15: 7-22.

Kim, Daesik, and Anthony M Santomero. 1988. Risk in banking and capital regulation. The Journal of Finance 43: 1219-33. [CrossRef]

Korinek, Anton, and Damiano Sandri. 2016. Capital controls or macroprudential regulation? Journal of International Economics 99: S27-S42. [CrossRef]

Kruithof, Maurits J. H. 2013. Basel III Capital Requirements. Amsterdam: University of Amsterdam.

Macit, Fatih. 2017. What determines the non-performing loans ratio: Evidence from Turkish commercial banks. CEA Journal of Economics 7: 33-39.

Maji, Santi Gopal, and Preeti Hazarika. 2018. Capital regulation, competition and risk-taking behavior of Indian banks in a simultaneous approach. Managerial Finance 44: 459-77. [CrossRef]

Maji Santi, Gopal. 2015. Regulatory capital and risk of Indian banks: A simultaneous equation approach. Journal of Financial Economic Policy 7: 140-56. [CrossRef]

Mollah, Sabur, M. Kabir Hassan, Omar Al Farooque, and Asma Mobarek. 2017. The governance, risk-taking, and performance of Islamic banks. Journal of Financial Services Research 51: 195-219. [CrossRef]

Munhoz, Vanessa da Costa Val, Larissa Naves de Deus, and Vanessa de Paula Pereira. 2017. Capital Flows to BRICS Countries during 2000-2010. Brazilian Keynesian Review 2: 211-38. [CrossRef]

Neanidis, Kyriakos C. 2019. Volatile capital flows and economic growth: The role of banking supervision. Journal of Financial Stability 40: 77-93. [CrossRef]

Nguyen, Ngoc Kim Chi. 2013. Basel III and The Risk Management of Banks in Vietnam. London: Royal Docks Business School, University of East London.

Nguyen, Thi Diem Kieu, and Tram Thi Xuan Huong. 2013. Factors Affecting Credit Risk Reserve in Vietnam's Commercial Banks. Ho Chi Minh City: University of Economics.

Nguyen, Thi Minh Hieu, and Phuong Thao Tran. 2015. Factors Affecting Credit Risk Provision in Vietnam's Commercial Banks. Ho Chi Minh City: University of Economics. 
Ozili, Peterson K. 2019. Non-performing loans and financial development: New evidence. The Journal of Risk Finance 20: 59-81. [CrossRef]

Pereira, Patricia, Eduardo Sá Silva, and Adalmiro Pereira. 2018. Operational risk management: The basel II. The International Journal of Business Management and Technology 2: 35-60.

Rubio, Margarita, and José A Carrasco-Gallego. 2016. The new financial regulation in Basel III and monetary policy: A macroprudential approach. Journal of Financial Stability 26: 294-305. [CrossRef]

Saunders, Anthony, and Linda Allen. 2010. Credit Risk Management In and Out of the Financial Crisis: New Approaches to Value at Risk and Other Paradigms, 3rd ed. Hoboken: John Wiley \& Sons, ISBN 978-0-470-47834-

Shrieves, Ronald E., and Drew Dahl. 1992. The relationship between risk and capital in commercial banks. Journal of Banking E Finance 16: 439-57.

Siddika, Aysa, and Razali Haron. 2019. Capital regulation and ownership structure on bank risk. Journal of Financial Regulation and Compliance 28: 39-56. [CrossRef]

Sirait, Rika Angelia, and Rofikoh Rokhim. 2019. Capital Adequacy Requirement, The Cost of Financial Intermediation and Risk Taking Behavior of The Indonesia Banking Sector. Paper presented at the 12th International Conference on Business and Management Research (ICBMR 2018), Bali, Indonesia, November 7-8.

Sutorova, Barbora, and Petr Teplý. 2013. The impact of Basel III on lending rates of EU banks. Finance a Uver 63: 226.

Taleb, Nassim Nicholas. 2007. The Black Swan: The Impact of the Highly Improbable. New York: Random House.

Tuladhar, Reema. 2017. Impact of Credit Risk Management on Profitability of Nepallese Commercial Banks. Sydney: Western Sydney University.

Uylangco, Katherine, and Siqiwen Li. 2016. An evaluation of the effectiveness of Value-at-Risk (VaR) models for Australian banks under Basel III. Australian Journal of Management 41: 699-718. [CrossRef]

Zetzsche, Dirk A., Ross P. Buckley, Janos N. Barberis, and Douglas W. Arner. 2017. Regulating a revolution: From regulatory sandboxes to smart regulation. Fordham Journal of Corporate \& Financial Law 23: 31.

Zhang, Zong-Yi, WU Jun, and Qiong-Fang Liu. 2008. Impacts of capital adequacy regulation on risk-taking behaviors of banking. Systems Engineering-Theory E Practice 28: 183-89.

Zheng, Changjun, Syed Moudud-Ul-Huq, Mohammad Morshedur Rahman, and Badar Nadeem Ashraf. 2017. Does the ownership structure matter for banks' capital regulation and risk-taking behavior? Empirical evidence from a developing country. Research in International Business and Finance 42: 404-21. [CrossRef] 